\title{
Sexual Violence and Other Complications of Corona Virus in Amhara Metropolitan Cities, Ethiopia
}

\author{
Lijalem Melie Tesfaw' \\ Aragaw Bizualem Kassie ${ }^{2}$ \\ Belaynesh Tazebew Flatie ${ }^{3}$ \\ 'Department of Statistics, Bahir Dar \\ University, Bahir Dar, Amhara Region, \\ Ethiopia; ' Institute of EiTEX, Bahir Dar \\ University, Bahir Dar, Amhara Region, \\ Ethiopia; ${ }^{3}$ Department of Biology, Bahir \\ Dar University, Bahir Dar, Amhara \\ Region, Ethiopia
}

Background: The onset of corona virus (COVID-19) pandemic brought about multiple crises with financial, social, and political dimensions, and problems involving absence or scarcity of medication, food, and other amenities. COVID led to reports of severe hunger, stress, sexual violence, and associated complications. This study was aimed at assessing the prevalence of sexual violence, hunger, stress, indoor fighting, and related complications caused by the corona virus, and determining factors associated with it.

Methods: A cross-sectional design study involving a total of 1288 participants recruited from Amhara Metropolitan cities was implemented. Each participant completed a questionnaire regarding experience of sexual violence, hunger, stress, indoor fighting, and other complications faced due to COVID-19. A statistical analysis was done by fitting binary logistic regression model, independent $t$-test and Chi-squared test.

Results: From the total participants, 1288 (26.2\%) were displaced, while $39.9 \%$ were unemployed due COVID-19. About half of the participants (48.8\%) experienced general distress, $33.8 \%$ faced sexual violence, $18.2 \%$ experienced hunger, $8.4 \%$ faced indoor fighting. The majority $(81.7 \%)$ of non-corona virus patients in government health-care institutions faced lack of treatment. For every unit increase of monthly income during COVID-19, the estimated odds of participants experiencing sexual violence decreased by $31.3 \%$ $(\mathrm{aOR}=0.687)$. Educational level, work status, and monthly salary before and during corona virus were important factors of hunger.

Conclusion: COVID-19 pandemic led to considerably high prevalence of sexual violence, hunger, stress, and indoor fighting. Work status of participants was an important associated factor of hunger, stress, and indoor fighting. Sex of participants and their monthly income were significantly associated with increase in sexual violence during COVID-19. In addition to a general economic recession, a decrease in treatment of non-COVID-19 patients was noticed, particularly in government hospitals.

Keywords: corona virus, sexual violence, hunger, stress, indoor fight, Ethiopia

\section{Introduction}

Following the first infections in China toward the end of 2019, corona virus continued to propagate across the world. No continent or country remained unaffected by the virus. ${ }^{1}$ About 1.52 million deaths, more than 65.54 million people infected, and 45.38 million recoveries were reported across the world. ${ }^{1,2}$ On 11 March 2020, the World Health Organization (WHO) declared the virus a global emergency and the pandemic impacted the entire world hugely. The pandemic continued to have economic, social, and political impact. ${ }^{4}$
Correspondence: Lijalem Melie Tesfaw Email lijalemmelie@gmail.com 
The impact of COVID-19 continues as an unsolved public health problem with potentially serious economic and social consequences. The outbreak of COVID-19 is particularly difficult for poor African countries due to their scarce economic resources, weak health system, and social crises. $^{2,22}$ The survey participants reported that about half of the global income and wealth losses occurred due to corona virus, the average losses being 5293 and 33,482 dollars, respectively as well as drops in employment, equity markets, consumer spending, and personal income. ${ }^{9}$ Many countries discontinued long-distance travel, closed or reduced civil service working hours, and government and non-government institutions, particularly, schools were partially/fully closed, or resorted to home based studies. ${ }^{1}$ Measures taken by developed countries to curb the pandemic involved closing borders and closing offices, which led to increased recession in the world economy in general and in the economy of developing countries in particular. ${ }^{2}$

In Africa, the pandemic progressed slowly and its harmful economic impact kept increasing. Key sectors of the African economy already experienced a slowdown because of the pandemic. ${ }^{2}$ Movement restrictions and quarantine measures resulted in less trade off, decrease in access to food, and decreased economic activities making the prices of basic items higher. As a result, people are forced to adopt negative handling mechanisms such as reducing food consumption, borrowing money for food. ${ }^{11}$ In this respect, female-headed households rather than male-headed ones suffered more adverse effects due to lack of shelter. ${ }^{11}$ One of the main preventive measures of COVID-19 that most countries used was lockdown, ie, staying at home. However, lockdown-related stress caused psychiatric problems, worsened emotional tension, and increased food and drink intake causing a dangerous health problem. Low and middle income countries, in contrast faced dietary problems leading to even worse poverty and malnutrition as a result of the corona virus. ${ }^{23}$

While school closures had acutely negative effects, mental health of children was exacerbated by lack of peer support and alternative means for mitigating risks. ${ }^{11}$ The corona virus crisis stretched poor health systems on the continent. The corona virus patients overcrowded the health facilities and patients with high burden diseases like AIDS, TB, and malaria were unable to obtain sustained care, which in turn led to more morbidity and mortality. ${ }^{2}$ Moreover, COVID-19 pandemic created shortage of medicines and health equipment. Weakness and slowness of the health care system led to irrelevant inability to ensure health care for all pandemic patients. ${ }^{24,25}$ Because of the drastic measures to reduced their medical supplies. Consequently, developing countries like Ethiopia faced difficulty in treating their patients after the pandemic gradually reached a critical stage. ${ }^{2}$

Due to the COVID-19 pandemic, social stress and gender-based violence are growing exponentially. Many women who are being forced to "lockdown" at home face their abusers when services that support them became increasingly inaccessible. ${ }^{3}$ In France, Singapore, and Argentina, cases of house fight increased by 30,33 , and $25 \%$, respectively. ${ }^{8}$ Since the corona virus outbreak began, such violence has also increased in Africa. ${ }^{3}$ Stress, the interruption of social and protective networks, and decreased access to services aggravate the risk of violence. ${ }^{4}$ As the world battles with the corona virus pandemic, emerging evidence indicates a sharp rise in genderbased violence in Ethiopia. For women and girls, this would have life-threatening consequences and profound impact on their opportunities and life trajectory. ${ }^{10}$

Numerous factors such as misinformation, lack of treatment, shortage of equipment, and lockdownassociated depression, anxiety, etc, aggravate vulnerability to the pandemic. ${ }^{6}$ Demographics such as occupation, age, gender, marital status, and occupation are factors that moderate covid-induced stress. COVID-19 led to job losses in Ethiopia. Such measures had especially bad impact on laborers and patients whose life standard relies on the hand to mouth. Owing to COVID-19 pandemic related crises, shortage of food and medical treatments became severe, leading to increased reports of hunger, stress, sexual violence and the like. This study, therefore, aimed at assessing the prevalence of corona related sexual violence, hunger, stress, indoor fighting as well as determining associated factors. Findings from such a study would enable policymakers and health institutions to update and adjust their covid-19 coping strategies.

\section{Methods}

\section{Study Design and Data}

A cross-sectional study design involving 1288 randomly recruited participants from six Amhara Metropolitan cities was implemented. The sample size was determined using binary logistic regression model with power of $80 \%$ and a significance level of $5 \% .{ }^{12}$ After the sample size was determined, the sample was allocated for each 
metropolitan city using proportional stratified sampling. A high number of participants recruited from sub-cities of the metropolitan area participated in the study.

A questionnaire that required participants to evaluate their experience of complications of corona virus such as sexual violence, hunger, stress, indoor fighting and others was used to collect data for the study. Based on a reference questionnaire employed in prior research, ${ }^{12,13}$ a questionnaire that investigated important socioeconomic, cultural, biological, and demographic determinants significantly associated with sexual violence, hunger, and indoor fighting because of corona virus was designed. The first draft of the questionnaire was prepared in English and translated into Amharic using standard translating procedures by experts so as to ensure semantic and content equivalence. A sample of forty residents selected through convenience sampling was recruited to ensure that the contents of the questionnaire was relevant to the community of city dwellers. The investigator made sure that the respondents wore masks while the questionnaire was disseminated, and sanitized their hands. The eligibility criteria for participation in this survey was age of 18 years or older.

\section{Variables in the Study}

In this study four complications of corona virus, namely sexual violence, hunger, indoor fighting, and stress were considered as the outcome variables (Table 1). Each participant was asked if they experienced sexual violence, hunger, stress, and/or indoor fighting during the pandemic with binary response of either yes (1) or no (0). On the other hand, twelve independent variables that determine the characteristics of the participants were considered (Table 1).

\section{Statistical Methods}

\section{Binary Logistic Regression}

Logistic regression is a statistical model used to determine the effects of a set of independent variables on categorical outcome variables. ${ }^{14}$ When the categorical values of the outcome variable are dichotomous, a particular logistic regression model called binary logistic regression is used. Since the outcome variables considered in this study contained dichotomous categorical values: yes $=1$ and no $=0$, binary logistic regression model was employed to analyze the data. For any binary outcome variables $\mathrm{Y}$ (yes=1, and no $=0$ ) and $X=\left\{\mathrm{x}_{1}, \mathrm{x}_{2}, \ldots, \mathrm{X}_{\mathrm{p}}\right\}$ factors, the probability that
Table I Variables' Description and Frequency Distribution

\begin{tabular}{|c|c|c|}
\hline Independent Variables & Categories (Codes) & $n(\%)$ \\
\hline Sex & $\begin{array}{l}\text { Male }(0) \\
\text { Female (I) }\end{array}$ & $\begin{array}{l}788(61.2) \\
500(38.8)\end{array}$ \\
\hline Religion & $\begin{array}{l}\text { Orthodox (I) } \\
\text { Muslim (2) } \\
\text { Protestant and others (3) }\end{array}$ & $\begin{array}{l}998(77.5) \\
215(16.7) \\
75(5.8)\end{array}$ \\
\hline City of residence & $\begin{array}{l}\text { Bahir Dar (I) } \\
\text { Debre Markos (2) } \\
\text { Gondar (3) } \\
\text { Dessie (4) } \\
\text { Woldya (5) } \\
\text { Debre Tabor (6) }\end{array}$ & $\begin{array}{l}240(18.6) \\
208(16.1) \\
222(17.2) \\
210(16.3) \\
205(15.9) \\
203(15.8)\end{array}$ \\
\hline Marital Status & $\begin{array}{l}\text { Single(I) } \\
\text { Married(2) } \\
\text { Windowed/divorced(3) }\end{array}$ & $\begin{array}{l}609(48.6) \\
546(43.5) \\
99(7.9)\end{array}$ \\
\hline Education level & $\begin{array}{l}\text { No education(I) } \\
\text { Grade I-8 (2) } \\
\text { Grade 9-12 (3) } \\
\text { College and above(4) }\end{array}$ & $\begin{array}{l}108(8.4) \\
189(14.7) \\
412(32.0) \\
579(42.3)\end{array}$ \\
\hline Displaced & $\begin{array}{l}\text { Yes (I) } \\
\text { No }(0)\end{array}$ & $\begin{array}{l}339(26.2) \\
950(73.8)\end{array}$ \\
\hline Regular work & $\begin{array}{l}\text { Employment (I) } \\
\text { Unemployment due to } \\
\text { COVID (2) } \\
\text { Unemployment even before } \\
\text { COVID (3) }\end{array}$ & $\begin{array}{l}594(46.1) \\
514(39.9) \\
180(14.0)\end{array}$ \\
\hline $\begin{array}{l}\text { Source of Information } \\
\text { about COVID }\end{array}$ & $\begin{array}{l}\text { Friends/family/neighbor (I) } \\
\text { Media (TV, radio, etc) (2) } \\
\text { Hospital/health expert (2) }\end{array}$ & $\begin{array}{l}247(19.2) \\
27(72.0) \\
114(8.8)\end{array}$ \\
\hline Permanent Residence & $\begin{array}{l}\text { Urban(0) } \\
\operatorname{Rural}(I)\end{array}$ & $\begin{array}{l}|13|(87.8) \\
157(12.2)\end{array}$ \\
\hline Age & $\begin{array}{l}\text { Mean } \\
29.9\end{array}$ & $\begin{array}{l}\text { Standard } \\
\text { deviation } \\
\text { II.3 }\end{array}$ \\
\hline $\begin{array}{l}\text { Monthly Income before } \\
\text { COVID-19 }\end{array}$ & 3945 & 4649.8 \\
\hline $\begin{array}{l}\text { Monthly Income during } \\
\text { COVID-19 }\end{array}$ & 2484 & 2849.8 \\
\hline Outcome variable & Categories (codes) & $n(\%)$ \\
\hline Sexual violence & $\begin{array}{l}\text { Yes (I) } \\
\text { No }(0)\end{array}$ & $\begin{array}{l}435(33.8) \\
953(66.2)\end{array}$ \\
\hline Hunger & $\begin{array}{l}\text { Yes ( } 1 \text { ) } \\
\text { No }(0)\end{array}$ & $\begin{array}{l}325(25.2) \\
963(79.8)\end{array}$ \\
\hline Indoor fighting & $\begin{array}{l}\text { Yes (1) } \\
\text { No (0) }\end{array}$ & $\begin{array}{l}108(8.4) \\
1180(91.6)\end{array}$ \\
\hline Stress & $\begin{array}{l}\text { Yes ( } 1) \\
\text { No }(0)\end{array}$ & $\begin{array}{l}629(48.8) \\
659(51.2)\end{array}$ \\
\hline
\end{tabular}


the sexual violence, hunger, stress or indoor fighting of the "ith" individual belongs to "yes $=1$ " of outcome variable given all possible factors $\mathrm{X}$ is given by $\mathrm{P}\left(\mathrm{Y}_{\mathrm{i}}=1 \mid X\right)$. Then, the binary logistic regression model is given by: ${ }^{14}$

$$
\begin{aligned}
\operatorname{logit}\left(P\left[Y_{i}=1 \mid X\right]\right) & =\log \left(\frac{P\left[Y_{i}=1 \mid X\right]}{1-P\left[Y_{i}=1 \mid X\right]}\right)=\alpha+X \beta, \\
i & =1,2, \ldots, 1288
\end{aligned}
$$

Where $\alpha$ is the intercept, $\mathrm{X}$ is matrix of all possible factors and $\beta$ its corresponding effect.

Data entry and organization were done using SPSS software. The data were then exported to SAS software, and statistical analyses such as fitting binary logistic regression and estimating adjusted odds ratio (aOR) with a $95 \%$ confidence interval were made using SAS software version 9.4, and interpreted.

\section{Independent $t$-Test}

A statistical test was applied to check whether the mean difference between two groups was significant. ${ }^{15}$ The monthly income difference of participants between, before, and during corona virus was evaluated using independent sample $t$-test.

\section{Ethical Considerations}

Ethical clearance was obtained from the Science College Research and Community Service Committee (SCRCSC) of Bahir Dar University, with a reference number of SCRCSC/102/02/12. Written informed consent was obtained from all participants. An identification number rather than names was assigned to keep personal information of participants in the study confidential, before completing the questionnaire all participants provided informed consent and confirmed that they participated on a voluntary basis.

\section{Results}

\section{Exploratory Data Analysis}

The independent and outcome variables and the frequency of participant within corresponding categories of the variable were presented in Table 1. From 1288 participants of this study, $61.2 \%$ were males, $77.5 \%$ were orthodox christians, $18.6 \%$ came from Bahir Dar metropolitan city, $48.6 \%$ had single marital status, and $42.3 \%$ had an educational level of college and above. Moreover, while 26.2\% of the participants were displaced, $39.9 \%$ were unemployed because of corona virus. The majority of the
Table 2 Monthly Income of Participants Before and During Corona Virus in Each Metropolitan City of Amhara Region, Ethiopia

\begin{tabular}{|l|c|c|c|c|}
\hline \multirow{2}{*}{$\begin{array}{l}\text { Metropolitan } \\
\text { City }\end{array}$} & \multicolumn{2}{|c|}{$\begin{array}{c}\text { Monthly Income } \\
\text { Before Corona } \\
\text { Virus }\end{array}$} & \multicolumn{2}{c|}{$\begin{array}{c}\text { Monthly Income } \\
\text { During Corona } \\
\text { Virus }\end{array}$} \\
\cline { 2 - 5 } & & $\begin{array}{c}\text { Standard } \\
\text { Deviation }\end{array}$ & Mean & $\begin{array}{c}\text { Standard } \\
\text { Deviation }\end{array}$ \\
\hline Bahir Dar & 3496.50 & 3579.13 & 2799.85 & 2877.89 \\
Gondar & 3756.44 & 5021.46 & 2418.92 & 2173.76 \\
Dessie & 4426.49 & 5912.89 & 3071.94 & 3410.60 \\
DebreMarkos & 2955.73 & 2084.76 & 2154.17 & 2712.90 \\
Woldya & 4391.35 & 4698.51 & 2919.27 & 2629.53 \\
Debre Tabor & 4828.55 & 5459.18 & 3499.07 & 2936.46 \\
\hline
\end{tabular}

participants $(72.0 \%)$ obtained updates about corona virus via media (TV, radio, etc.). The average age of the participants was 29.9 (years), and the average monthly income before and during corona virus was 3945 and 2484 birr, respectively.

$25.2 \%$ of the study participants experienced hunger, $33.8 \%$ faced sexual violence, $8.4 \%$ faced indoor fighting, while $48.8 \%$ had stress related to COVID-19 (Table 1).

Table 2 depicted average monthly income of participants before and during corona virus per each metropolitan city in Amhara region, Ethiopia. As compared to before the onset of COVID-19, in all of the cities, monthly income of participants decreased during corona virus.

In Table 3, whether there was significant difference between average monthly income before and during COVID-19 was checked using independent $t$-test. Thus, significant difference was noticed in the average monthly income between before and during COVID-19 (p-value $=0.001<0.05)$.

While Tables 2 and 3 showed the economic recession due to corona virus, Table 4 showed the impact of corona virus on the health sector. As the demand of corona virus patients increased, $28.5 \%$ of the participants realized that treatment of non-corona virus patients decreased during

Table 3 Testing overall average monthly income difference between before and during COVID-19 using independent $t$-Test

\begin{tabular}{|l|l|l|l|}
\hline $\begin{array}{l}\text { Average } \\
\text { monthly } \\
\text { income before } \\
\text { COVID-19 }\end{array}$ & $\begin{array}{l}\text { Average } \\
\text { monthly } \\
\text { income during } \\
\text { COVID-19 }\end{array}$ & $\begin{array}{l}\text { Average } \\
\text { monthly } \\
\text { income } \\
\text { difference }\end{array}$ & p-value \\
\hline 3945.06 & 2485.00 & 1460.06 & 0.001 \\
\hline
\end{tabular}


Table 4 Exploring the Impact of Corona Virus on Treatment for Non-COVID-I 9 Patients at Hospital

\begin{tabular}{|l|l|l|}
\hline Items & Categories & $\mathbf{n ( 5 )}$ \\
\hline I. Treatment for non-corona virus patients during corona virus & $\begin{array}{l}\text { Decreased (I) } \\
\text { Same (2) } \\
\text { Increased (3) }\end{array}$ & $\begin{array}{l}367(28.5) \\
857(66.5) \\
64(5.0)\end{array}$ \\
\hline $\begin{array}{l}\text { 2. If you say "decreased in I", in which sector did treatment of non-corona virus patients decrease? } \\
\text { Government health sector (I) }\end{array}$ & $\begin{array}{l}\text { 300 (8I.7) } \\
67(18.3)\end{array}$ \\
\hline $\begin{array}{l}\text { Private health sector (2) } \\
\text { treatment? }\end{array}$ & $\begin{array}{l}\text { Yes (I) (5.7) } \\
\text { No (2) }\end{array}$ & $\begin{array}{l}\text { During birth (I) } \\
\text { Bleeding (2) } \\
\text { Chronic and Infectious } \\
\text { disease (3) }\end{array}$ \\
\hline 4. Based on 3, what was the cause of death? & $\begin{array}{l}8(38.1) \\
4(19.0) \\
9(42.9)\end{array}$ \\
\hline
\end{tabular}

the pandemic, while only $5.0 \%$ of participants' treatments increased for non-COVID-19 patients. The majority $(81.7 \%)$ of non-COVID-19 patients that did not get treatment were from government health sector. Of the 367 participants who did not get in government $5.7 \%$ of them lost their family/friends/neighbor/or relatives. From the 21 individuals who lost their life due to lack of treatment in hospitals, $38.1 \%$ were mothers who went there for giving birth.

The bivariate analysis depicted the presence of association of independent variables with corona virus complications such as sexual violence, hunger, stress, and indoor fighting, Table 5. Sex, marital status, residence, education level, displacement status, work status, and permanent residence were significantly associated ( $p$-value $<0.05$ ) with sexual violence. The majority of participants who faced sexual violence were female (95.2\%), single (53.1\%), illiterate (42.3\%), unemployed due to COVID-19 (45.7\%), and urban dwellers (85.7\%). City of residence, educational level, and work status were significantly associated with hunger. $43.5 \%$ of the participants who experienced hunger were unemployed due to COVID-19. Participants' employment status was significantly associated with stress and indoor fighting. Many of the participants that faced stress (38.5\%) and that were involved in indoor fighting (42.7\%) were those who were unemployed due to COVID-19.

Table 6 depicts the association between outcome variables, COVID-19-induced complications, such as sexual violence, hunger, stress, and indoor fighting. The p-value which was less than 0.05 indicates that there was a significant association between the two outcome variables. It showed that sexual violence was significantly associated with stress and indoor fighting. Moreover, a significant association was seen between hunger and stress, as well as between stress and indoor fighting.

This study measured sexual violence using four "yes" or "no" question items. A participant who responded "yes" to at least one question was considered a victim of sexual violence. Among a total of 435 sexual violence victims during COVID-19, 32.8\% of the violence was committed without the willingness of the spouse. After the closure of schools due to corona virus, $113(26.0 \%)$ were obligated to get married (Table 7).

\section{Model Fitting}

The estimated effects of independent variables on sexual violence, hunger, stress, and indoor fighting due to corona virus using binary logistic regression model was fitted in Table 8 . The estimated odds ratio was computed for each covariate. The odds ratio (OR) is a natural measure to describe whether independent variables had significant effects on categorical outcome of interest. ${ }^{16}$ An OR different from one indicates that the independent variable had a significant effect on the outcome of interest. The fitted binary logistic regression model depicted that the sex of participants, city of residence, source of information, and monthly income during COVID-19 were important determinants of sexual violence against participants. The estimated odds of male participants that experienced sexual violence were 0.523 times the estimated odds of female participants. This indicates that female participants were more susceptible to sexual violence than males. For a unit increase of monthly income during COVID-19, the estimated odds of participants experience of sexual 
Table 5 Bivariate Analysis of Factors That were Associated with COVID-19 Complications: Sexual Violence, Hunger, Stress, and Indoor Fighting in Amhara Metropolitan Cities, Ethiopia

\begin{tabular}{|c|c|c|c|c|}
\hline \multirow[t]{2}{*}{ Characteristics } & \multicolumn{4}{|c|}{ Corona Virus Complication } \\
\hline & $\begin{array}{l}\text { Sexual Violence } n=435 \\
(\%)\end{array}$ & $\begin{array}{l}\text { Hunger } n=325 \\
(\%)\end{array}$ & $\begin{array}{l}\text { Stress } n=629 \\
(\%)\end{array}$ & $\begin{array}{l}\text { Indoor Fighting } n=108 \\
\text { (\%) }\end{array}$ \\
\hline \multicolumn{5}{|l|}{ Sex } \\
\hline Male & $21(4.8)^{*}$ & $122(37.4)$ & $381(60.6)$ & $64(59.3)$ \\
\hline Female & $414(95.2)$ & $203(62.6)$ & $248(39.4)$ & $44(40.7)$ \\
\hline \multicolumn{5}{|l|}{ Religion } \\
\hline Orthodox & $327(75.2)$ & $158(48.5)$ & $407(64.7)^{* * *}$ & $58(53.7)$ \\
\hline Muslim & $73(17.0)$ & $90(27.9)$ & $122(19.4)$ & $27(25.0)$ \\
\hline Protestant and others & $35(7.8)$ & $77(23.6)$ & $100(15.9)$ & $23(21.3)$ \\
\hline \multicolumn{5}{|l|}{ Marital Status } \\
\hline Single & $231(53.1)^{*}$ & $122(37.4)$ & $280(44.5)^{*}$ & $53(49.0)$ \\
\hline Married & $119(27.4)$ & $90(27.7)$ & $254(40.4)$ & $41(38.0)$ \\
\hline Windowed/divorced & $85(19.5)$ & $113(34.9)$ & $95(15.1)$ & $14(13.0)$ \\
\hline \multicolumn{5}{|l|}{ City of residence } \\
\hline Bahir Dar & $41(19.5)^{* * *}$ & $64(19.7)^{* * *}$ & $142(22.6)^{* * *}$ & $22(20.4)^{* * * *}$ \\
\hline Debre Markos & $75(13.4)$ & $56(17.2)$ & $103(16.4)$ & $23(21.3)$ \\
\hline Gondar & $95(20.1)$ & $48(14.8)$ & $99(15.7)$ & $20(18.5)$ \\
\hline Dessie & $64(2 \mid .5)$ & $44(13.5)$ & $101(16.1)$ & II (I0.2) \\
\hline Woldya & $95(24.2)$ & $66(20.3)$ & $94(14.9)$ & $17(15.7)$ \\
\hline Debre Tabor & $65(18.0)$ & $47(14.5)$ & $91(14.5)$ & $15(13.9)$ \\
\hline \multicolumn{5}{|l|}{ Education level } \\
\hline No education & $184(42.3)^{* * *}$ & $138(42.5)^{* * *}$ & $140(22.3)$ & $28(25.5)$ \\
\hline Grade I-8 & $15 \mid(30.7)$ & $98(30.1)$ & $123(19.5)$ & $34(31.5)$ \\
\hline Grade 9-12 & $75(17.2)$ & $36(11.0)$ & $121(19.3)$ & $24(22.1)$ \\
\hline College and above & $25(5.8)$ & $53(16.4)$ & $245(38.9)$ & $22(20.4)$ \\
\hline \multicolumn{5}{|l|}{ Displaced } \\
\hline Yes & $166(38.1)^{* *}$ & I 44 (44.2) & $215(34.2)$ & $27(0.25)$ \\
\hline No & $269(61.9)$ & I8I (55.8) & $4 \mid 4(65.8)$ & $81(0.75)$ \\
\hline \multicolumn{5}{|l|}{ Work Status } \\
\hline Employed & $107(24.6)^{*}$ & $49(15.0)^{* *}$ & $192(30.5)^{*}$ & $21(19.3)^{*}$ \\
\hline Unemployed (due to corona virus) & $199(45.7)$ & $|4|(43.5)$ & $242(38.5)$ & $46(42.7)$ \\
\hline $\begin{array}{l}\text { Unemployed (even before corona } \\
\text { virus) }\end{array}$ & $129(29.7)$ & $135(4 \mid .5)$ & $195(31.0)$ & $4 \mid(38.0)$ \\
\hline \multicolumn{5}{|l|}{ Permanent Residence } \\
\hline Rural & $62(14.3)^{* *}$ & $27(8.3)$ & $69(11.0)$ & $29(26.9)^{*}$ \\
\hline Urban & $373(85.7)$ & $298(91.7)$ & $560(89.0)$ & $79(73.1)$ \\
\hline \multicolumn{5}{|l|}{ Source of information } \\
\hline Friends/family/neighbor & 91 (20.9)* & $73(22.5)$ & $182(28.9)$ & $20(18.5)$ \\
\hline Media (TV, radio, etc) & $264(60.7)$ & $150(46.0)$ & $267(42.5)$ & $75(69.5)$ \\
\hline Hospital/health expert & $80(18.4)$ & $102(31.4)$ & $180(28.6)$ & $13(12.0)$ \\
\hline
\end{tabular}

Note: $* * *$ p-value $\leq 0.001,{ }^{*}$ p-value $\leq 0.01,{ }^{*}$-value $\leq 0.05$

violence decreased by $31.3 \%(\mathrm{aOR}=0.687)$. Educational level, work status, and monthly income before and during COVID-19 were important factors of hunger. The estimated odds of hunger among non-educated participants were 1.924 times the estimated odds of college-educated and above participants, which indicates that non-educated 
Table 6 Association Between Ccomplications of Corona Virus

\begin{tabular}{|l|l|l|l|}
\hline & Hunger & Stress & Indoor fighting \\
\hline Sexual violence & 0.305 & $\mathbf{0 . 0 4 4}$ & $\mathbf{0 . 0 2 5}$ \\
Hunger & $\mathbf{0 . 0 0 1}$ & 0.056 & \\
Stress & $\mathbf{0 . 0 0 5}$ & & \\
\hline
\end{tabular}

Table 7 Question Items of Sexual Violence

\begin{tabular}{|l|l|}
\hline Items & n (\%) \\
\hline $\begin{array}{l}\text { I was obligated to have sexual intercourse with my } \\
\text { partner without my willingness. }\end{array}$ & I43 (32.8) \\
\hline $\begin{array}{l}\text { I was obligated to have sexual intercourse with } \\
\text { someone other than my partner. }\end{array}$ & $80(18.4)$ \\
\hline $\begin{array}{l}\text { I have a friend/relative who was obligated to have sex } \\
\text { without their willingness. }\end{array}$ & $99(22.8)$ \\
\hline $\begin{array}{l}\text { As schools are closed due to the corona virus, I was } \\
\text { obligated to get married. }\end{array}$ & II3 (26.0) \\
\hline Total & $435(100)$ \\
\hline
\end{tabular}

participants were more vulnerable to hunger than participants with an educational level of college graduate and above.

Participants' sex, residence, work status, permanent residence, and monthly income before COVID-19 had significant effect on the stress level of the participants. Metropolitan residence, work status, and monthly income were important determinants of indoor fighting during corona virus. The estimated odds of stressed male participants were 1.294 times the estimated odds of female participants indicating that, as compared to female participants, male participants were more likely to become distressed. As compared to participants unemployed before the corona virus, participants unemployed due to COVID19 were more likely to be stressed $(\mathrm{aOR}=1.688)$. The estimated odds of rural participants to become stressed were 0.801 times the estimated odds of urban participants.

This indicates that rural participants were less likely to be stressed than urban participants. While the estimated odds of participants to become stressed decreased by $6.8 \%$ $(\mathrm{aOR}=0.932)$, per a unit (in birr) increase of monthly income before COVID-19. City of residence, work status and monthly salary during COVID-19 were significant determinants that affected indoor fighting among participants. The estimated odds of participants who were unemployed during corona virus being a victim of indoor fighting were 2.033 times the estimated odds of those who were unemployed before COVID-19, which indicates that participants unemployed during corona virus were more likely to have more indoor fighting than their counterparts. The estimated odds of participants to be victims of indoor fighting decreased by $38.0 \%$ $(\mathrm{aOR}=0.620$ ), for a unit (in birr) increase of monthly income during COVID-19. This indicates that compared to participants with lower income, participants with higher income were less likely to be involved in indoor fighting.

\section{Discussion}

Since the outbreak of corona virus in China, several studies have been conducted on the virus and how it impacted the developed countries economically, politically, socially, and culturally. However, in developing countries such as Ethiopia, limited research has been done on the impact of the virus. This study, was thus aimed at assessing the prevalence of sexual violence, hunger, stress, indoor fighting, and other COVID-19 complications in Amhara metropolitan cities of Ethiopia. In addition, factors associated with the complications of corona virus were also determined. Our results give early insight into the urgent need to provide continued care and remedial action on sexual violence, hunger, stress and indoor fighting due to COVID-19. This work will help international bodies intervene to help stop the crisis.

As outcome variables had binary outcomes (yes or no), in order to determine the factors significantly associated with them, binary logistic regression model was interpreted using odds ratio (OR). ${ }^{16}$ To evaluate the association between these complications of corona virus, Chi-square $\mathrm{d}$ test was applied.

The prevalence of sexual violence, hunger, stress, indoor fighting, and other complications did not decrease. Nearly one third of the participants (33\%) included in the study were victims of sexual violence during corona virus. The figure in this finding was higher than that of figures from studies in Addis Ababa (12.7\%), Medawalabu (10.9\%), and Hawassa (10.2\%) metropolitan cities of the country before corona virus began. ${ }^{17}$ A study in ${ }^{5}$ reported higher incidence of physical intimate violence during COVID-19 pandemic compared with the prior three years. This might be due to the differences in age, sociocultural factors, and other characteristics between study participants beyond the impact of corona virus. The majority of the sexual violence occurred due to a partner while the rest was committed by someone other than a partner. 
Table 8 Fitting Binary Logistic Regression Model to Estimate the Effect of Independent Variables on Complications Due to Corona Virus: Sexual Violence, Hunger, Stress, and Indoor Fighting in Amhara Metropolitan Cities Community, Ethiopia

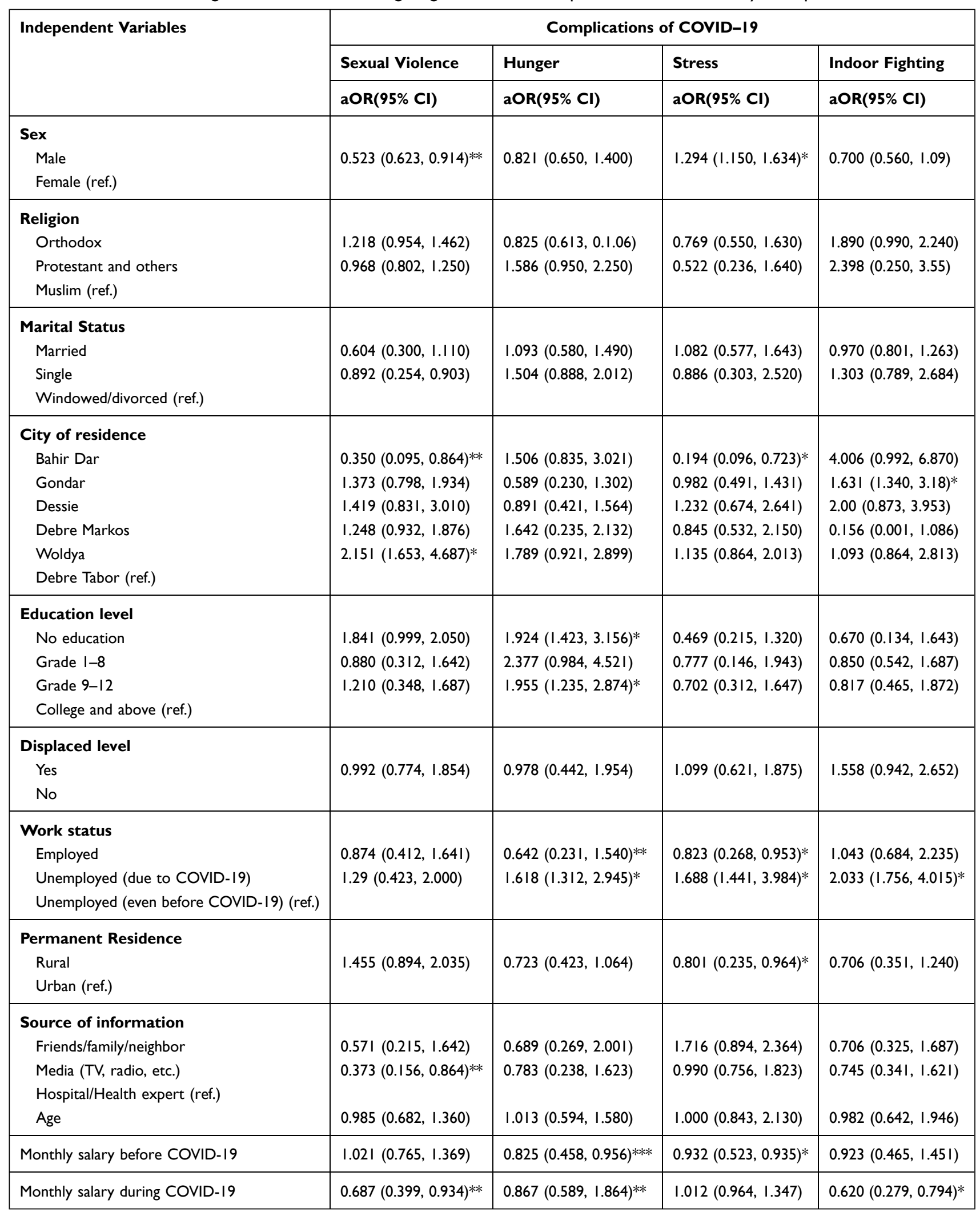

Note: ***-value $\leq 0.00 \mathrm{I},{ }^{*}$ p-value $\leq 0.0 \mathrm{I},{ }^{*} \mathrm{p}$-value $\leq 0.05$.

Abbreviations: aOR, adjusted odds ratio; $\mathrm{Cl}$, confidence interval; ref, reference. 
This finding was consistent with findings from a study that involved only women ${ }^{18}$ in which it was reported that more than half of the women experienced violence from their partner including sexual violence. Among participants who were victims of sexual violence, $113(26.0 \%)$ were students forced to get married by their parents, and without their consent because the schools were closed due to the pandemic. Compared to sexual violence against men $(4.8 \%)$, the incidence of sexual violence against women was extremely high $(95.2 \%)$, a finding which is in line with studies by. ${ }^{17,18}$ This study also demonstrated that sex of the participants, city of residence, source of information about COVID-19, and monthly income during COVID-19 were important determinants of sexual violence. As compared to participants from Debre Tabor city, participants from Woldya city were more prone to experiencing sexual violence. This could be due to the fact that Woldya city is a border city interconnecting people from different places and is a site of varied commercial exchange. Participants with low monthly salary during COVID-19 had higher likelihood of experiencing sexual violence. This finding is in line with another finding from another study on women $^{4,18}$ which found that, compared to higher income women, poorer women experienced increased sexual violence.

Even though at the level of Sub-Saharan Africa, Ethiopia has made remarkable economic strides in becoming one of the efficient economies, at a global level, it is still one of the poorest nations with a hungerstricken population. ${ }^{19}$ Distancing measures were taken and people were encouraged to stay home, stopping their work. $^{4,21}$ Nonetheless, corona virus pandemic aggravated the burden and prevalence of hunger. This study revealed that more than a quarter of participants $(25.2 \%)$ experienced hunger. The authors think that the number of hungry participants could be even higher because many participants feel ashamed to tell the truth about their experience of hunger. The authors noticed that even most of the street workers employed in small and micro works were prohibited from working by the government to reduce the spread of the pandemic, and suffered inside their homes.

As most of them were head of the family rather than just individuals, they faced collateral damage. A woman interviewed arbitrarily about the current complications of COVID-19 while she was preparing coffee on the streets replied "for me I do not mind if I spend the whole day and night without any food but I always worry about whether
I would afford to feed my child and to pay the rent for my living room". Educational level, work status, monthly income before and during COVID-19 were significant factors that were associated with hunger. Participants with an educational level of college and above were less likely to be hungry compared with participants who did not have any education. This finding is consistent with findings from several studies in developing countries, ${ }^{19,20}$ which indicated that educational level is an important factor associated with under-nutrition. Compared with low monthly income participants, participants with higher monthly income before and during COVID-19 were less likely to face hunger.

Nearly half of participants $(48.8 \%)$ experienced stress due to corona virus pandemic. In studies where impact of corona virus was reported, ${ }^{8}$ it was noticed that continued COVID-19 pandemic induced fear and worry in daily life. Unlike findings from a study by, ${ }^{6}$ sex of participant was a significant factor associated with stress, while marital status had no relation with stress. Moreover, work status, participants' permanent residence, and monthly income before corona virus were important determinants of stress. Participants unemployed due to COVID-19 were more likely to be stressed than employed and participants and those unemployed before COVID-19.

As in many countries, Ethiopia adopted quarantine, social isolation, stay at home orders, etc following COVID-19 incidence. ${ }^{7}$ However, despite these measures, social impact of COVID-19 such as indoor fighting increased. This study found that $8.4 \%$ of the participants experienced indoor fighting during the pandemic. Monthly income during COVID-19 and work status were important determinants of indoor fighting. Beyond COVID-19's social impact, this study also found that in government hospitals, lack of treatment for non-COVID-19 patients and economic recession were noticed. This aligns with findings from studies by. $^{2,9}$ It also indicated that ${ }^{26}$ corona virus impacted mental health. This was noticed toward the onset of the pandemic. The traumatic experiences and affective disorders significantly affected quality of life. ${ }^{27}$ In general, in addition to the impact COVID-19 caused, higher prevalence of sexual violence, hunger, stress, and indoor fighting ensued due to corona pandemic, thus, the government, health institutions as well as stakeholders should engage in actions that salvage people from the diverse damage and impact of Covid-19. 


\section{Conclusion}

The prevalence of sexual violence, hunger, stress, and indoor fighting due to COVID-19 pandemic was considerably high. Work status of participants was an important factor that was associated with hunger, stress, and indoor fighting. Monthly income during COVID-19 and sex of participants were significantly associated with sexual violence. Moreover, in government hospitals especially, there was lack of treatment for non-COVID-19 patients. Economically, covid-19 brought a recession. These all call for timely remedial action from the government and other stakeholders. In order to reduce the damage of COVID-19 pandemic would put into question the survival of many among the society whose life hangs on a hand to mouth subsistence.

\section{Abbreviations}

WHO, World Health Organization; COVID, Corona Virus Disease; aOR, Adjusted Odds ratio; CI, Confidence Interval; SCRCSC, Science College Research and Community Service Committee.

\section{Data Sharing Statement}

The datasets used and/or analyzed during the current study are available from the corresponding author on reasonable request.

\section{Ethics Approval and Consent to Participate}

The study was conducted in full accordance with the World Medical Association Declaration of Helsinki and approved by the Ethics Committee of Science College Research and Community Service of Bahir Dar University, Ethiopia (SCRCSC/102/02/12).

\section{Acknowledgments}

We would like to thank our data collectors, the supervisor, the study participants, City Administrative Office in Amhara region, and Bahir Dar University academic and administrative workers for their cooperation and assistance during the data collection. The manuscript was edited for language by BerhanuEngidaw (PhD), department of English language and literature, Bahir Dar University.

\section{Author Contributions}

Tesfaw had the idea of the study. All authors contributed to data analysis, drafting or revising the article, have agreed on the journal to which the article will be submitted, gave final approval of the version to be published, and agree to be accountable for all aspects of the work.

\section{Funding}

This research was funded by Bahir Dar University.

\section{Disclosure}

The authors declare that they have no competing interests.

\section{References}

1. Douedi, S. and Miskoff, J., 2020. Novel coronavirus 2019 (COVID19): a case report and review of treatments. Medicine, 99(19).

2. Lone SA, Ahmad A. COVID-19 pandemic-An African perspective. Emerg Microb Infect. 2020;9(1):1-28.

3. Women UN. Policy Brief: The Impact of COVID-19 on women. New York (NY): United Nations; 2020.

4. World Health Organization. COVID-19 and violence against women: what the health sector/system can do, 7 April 2020 (No. WHO/SRH/ 20.04). World Health Organization; 2020.

5. Gosangi B, Park H, Thomas R, et al. Exacerbation of physical intimate partner violence during COVID-19 lockdown. Radiology. 2020;298(1)202866.

6. Islam SDU, Bodrud-Doza M, Khan RM, Haque MA, Mamun MA. Exploring COVID-19 stress and its factors in Bangladesh: a perception-based study. Heliyon. 2020;6(7):e04399. doi:10.1016/j. heliyon.2020.e04399

7. Fitzpatrick KM, Drawve G, Harris C. Facing new fears during the COVID-19 pandemic: the State of America's mental health. J Anxiety Disord. 2020;75:102291. doi:10.1016/j.janxdis.2020.102291

8. Sharifi F, Larki M, LatifnejadRoudsari R. COVID-19 outbreak as threat of violence against women. J Midwif Reprod Health. 2020;8 (3):2376-2379.

9. Coibion O, Gorodnichenko Y, Weber M. The cost of the covid-19 crisis: lockdowns, macroeconomic expectations, and consumer spending (No. w27141). NBER. 2020.

10. Oguntayo R, Oyeleke JT, John-Oguntayo O, Aajayi-Hutchful FA. Personality traits, emotional intelligence, socio-contextual factors and spousal violence: the trajectory of COVID-19 pandemic lockdown. Int J Behav Sci. 2020;14(2):101-107.

11. Lokot M, Avakyan Y. Intersectionality as a lens to the COVID-19 pandemic: implicationsfor sexual and reproductive health in development and humanitarian contexts. Sex Reprod Health Matters. 2020;28(1):1-5.

12. Wong CL, Chen J, Chow KM, et al. Knowledge, attitudes and practices towards COVID-19 amongst ethnic minorities in Hong Kong. Int $J$ Environ Res Public Health. 2020;17(21):7878. doi:10.3390/ijerph17217878

13. Chan EY, Cheng CK, Tam G, Huang Z, Lee P. Knowledge, attitudes, and practices of Hong Kong population towards human A/H7N9 influenza pandemic preparedness, China, 2014. BMC Public Health. 2015;15(1):943. doi:10.1186/s12889-015-2245-9

14. HosmerJr DW, Lemeshow S, Sturdivant RX. Applied Logistic Regression. John Wiley andSons; 2013.

15. Sedgwick P. Independent samples t test. BMJ. 2010;340(5):c2673. doi:10.1136/bmj.c2673

16. Montgomery DC, Runger GC. Applied Statistics and Probability for Engineers. John Wiley and Sons; 2010.

17. Adinew YM, Hagos MA. Sexual violence against female university students in Ethiopia. BMC Int Health Hum Rights. 2017;17(1):1-7. doi:10.1186/s12914-017-0127-1 
18. Semahegn A, Mengistie B. Domestic violence against women and associated factors in Ethiopia; systematic review. Reprod Health. 2015;12(1):78. doi:10.1186/s12978-015-0072-1

19. Amsalu A. Eradicating extreme poverty and hunger in Ethiopia: a review of development strategies, achievements, and challenges in relation with MDG1. NCCR NorthSouth; 2012.

20. Mengistu K, Alemu K, Destaw B. Prevalence of malnutrition and associated factors among children aged 6-59 months at HidabuAbote District, North Shewa, Oromia Regional State. J Nutr Disord Ther. 2013;1(T1):1-15. doi:10.4172/2161-0509-3-T1-001

21. Zikargae MH. COVID-19 in Ethiopia: assessment of how the ethiopian government has executed administrative actions and managed risk communications and community engagement. Risk Manag Healthc Policy. 2020;13:2803-2810. doi:10.2147/RMHP.S278234

22. Napoli PE, Nioi M. Global spread of coronavirus disease 2019 and malaria: an epidemiological paradox in the early stage of a pandemic; 2020.

23. Napoli PE, Nioi M, Fossarello M. The "quarantine dry eye": the lockdown for coronavirus disease 2019 and its implications for ocular surface health. Risk Manag Healthc Policy. 2021;14:1629. doi:10.2147/RMHP.S277067
24. Napoli PE, Nioi M, d'Aloja E, Fossarello M. Safety recommendations and medical liability in ocular surgery during the COVID-19 pandemic: an unsolved dilemma; 2020.

25. Nioi M, Napoli PE, Lobina J, Fossarello M, d'Aloja E. COVID-19 and Italian healthcare workers from the initial sacrifice to the mRNA vaccine: pandemic chrono-history, epidemiological data, ethical dilemmas, and future challenges. Front Public Health. 2020;8:591900. doi:10.3389/fpubh.2020.591900

26. Amerio A, Bianchi D, Santi F, et al. Covid-19 pandemic impact on mental health: a web-based cross-sectional survey on a sample of Italian general practitioners. Acta Biomed. 2020;91(2):83-88.

27. Serafini G, Gonda X, Pompili M, Rihmer Z, Amore M, Engel-Yeger B. The relationship between sensory processing patterns, alexithymia, traumatic childhood experiences, and quality of life among patients with unipolar and bipolar disorders. Child Abuse Negl. 2016;62:39-50. doi:10.1016/j.chiabu.2016.09.013
Risk Management and Healthcare Policy

\section{Publish your work in this journal}

Risk Management and Healthcare Policy is an international, peerreviewed, open access journal focusing on all aspects of public health, policy, and preventative measures to promote good health and improve morbidity and mortality in the population. The journal welcomes submitted papers covering original research, basic science, clinical \& epidemiological studies, reviews and evaluations,

\section{Dovepress}

guidelines, expert opinion and commentary, case reports and extended reports. The manuscript management system is completely online and includes a very quick and fair peer-review system, which is all easy to use. Visit http://www.dovepress.com/testimonials.php to read real quotes from published authors. 